\title{
Characteristics of Sertoli cells in the ectopic and scrotal testes of unilateral cryptorchid West African dwarf goats
}

\author{
O.C. Godwin, E.N. Daniel \\ Department of Veterinary Anatomy, University of Nigeria, Nsukka, Nigeria \\ [Received: 17 August 2015; Accepted: 17 October 2015]
}

\begin{abstract}
Sertoli cell population and histology were studied in testes of unilateral cryptorchid goats. Histomorphological and electron microscopic techniques were employed. The results demonstrated that the number of Sertoli cell per testis was significantly $(p<0.05)$ higher in the descended scrotal testes of unilateral cryptorchid bucks compared with the right and left testes of the normal bucks, respectively. However there was no significant difference $(p>0.05)$ on comparing the number of Sertoli cells in the scrotal testes of the unilateral cryptorchid bucks with the paired testes of the normal bucks. Significant differences were not observed in the dimensions of the Sertoli cell nuclei in the retained, scrotal testes of the cryptorchids and the testes of the normal bucks. The Sertoli cells of the descended scrotal testes of the cryptorchid bucks and those of the normal bucks showed histological evidence of normal activity. Degeneration of Sertoli cells was observed in the retained testis of the cryptorchid bucks. The failure of one testis to descend most probably influenced compensatory hyperplasia of Sertoli cells and enhanced function of the cells in the descended testis of the unilateral cryptorchids. (Folia Morphol 2016; 75, 3: 355-363)
\end{abstract}

Key words: Sertoli cell, population, histology, cryptorchidism

\section{INTRODUCTION}

West African Dwarf goat (WAD) is the predominant breed of goat in Southern Nigeria. Its preference for browsing on a wide variety of vegetation, its ability to withstand the extremes of tropical climate account for its widespread distribution throughout West, Central and East Africa, India and Fiji [23, 24]. These goats are largely unimproved genetically, but show a certain degree of tolerance or resistance to trypanosomiasis [6]. Among the WAD goats of Eastern Nigeria, unilateral cryptorchidism has been described as a common condition [8, 9]. Cryptorchidism is a condition where one (unilateral) or both (bilateral) testes fail to descend into the scrotum $[20,22]$. In men with unilateral cryptorchidism, tumour of the scrotal testis has been reported [14]. Pinart et al. [25] has suggested abnormal and incomplete spermatid maturation in the scrotal testis due to abnormal structure and function of Sertoli cells. Changes in Sertoli cell structure associated to cryptorchidism include, increased lipid content and vacuolisation of Sertoli cells [11], degeneration of smooth endoplasmic reticulum and changes in inter Sertoli cell junctions [4] in the retained testis. In the goat, study of the characteristics of Sertoli cells in the scrotal testis in unilateral cryptorchids has received little attention.

The few available studies remain a source of concern as some found incomplete development and

Address for correspondence: Dr O.C. Godwin, Department of Veterinary Anatomy, University of Nigeria, Nsukka, Nigeria, tel: +2347032996765 , e-mail: godwin.okpe@unn.edu.ng 
morphological abnormalities while others found normal Sertoli cell morphology [31]. Moreover, most of the available information was based on descriptive histology. No definitive studies have assessed changes in Sertoli cell population in the retained and descended testes of unilateral cryptorchid bucks. The influence of unilateral cryptorchidism on Sertoli cell population remains to be clarified. The unavailability of enough information is worrisome as a high correlation between the absolute number of Sertoli cells per paired testis and daily sperm production has been established $[16,29]$. The present study is therefore aimed at examining the morphology and population of Sertoli cells in (abdominally) retained and descended (scrotal) testes of unilateral cryptorchid goats. This may provide further information on the effect of unilateral cryptorchidism on the contralateral descended testes.

\section{MATERIALS AND METHODS}

\section{Compliance with ethical standard}

Permission was obtained from the University of Nigeria Ethics Committee on the use and care of animals for experiment. The guidelines for the care and use of animals for experiment were strictly followed.

\section{Animals}

Forty adult male WAD goats aged 14-20 months (average age of 17 months) and weighing between 8 and $10 \mathrm{~kg}$ (average weight of $9.5 \mathrm{~kg}$ ) were used for the study. The ages of the bucks were estimated by dentition method as described by Mitchell [21]. The bucks were divided into two groups, Group A ( 20 bucks with fully descended testes) and Group B (20 bucks with unilaterally descended testis). Group A served as control group while Group B was the experimental group. The animals were apparently healthy. They were fed with giant star grass, elephant grass and spent maize grain. Water was provided ad libitum.

\section{Tissue processing for light and electron microscopy}

Ten bucks from each group were euthanised with an overdose of $20 \%$ pentobarbitone sodium (SagatalR, Animal Care Ltd., United Kingdom). Testes samples were processed for semi and Ultrathin sections as described below.

Modified Karnovsky fixative composed of $2 \%$ paraformaldehyde and $2.5 \%$ glutaraldehyde in $0.1 \mathrm{M}$ phosphate buffer at $\mathrm{pH} 7.4$ was used as prima- ry fixative. The fixing agent was administered by perfusion as described by Ezeasor [10]. Testes were dissected out and weighed. The volume of testes was determined by water displacement technique. The tunica albuginea was separated from the testes parenchyma and both the tunica albuginea and parenchyma were weighed respectively. 2-4 mm thick testis samples taken from each buck were post fixed in $\mathrm{OsO} 4$ in Millonig's buffer, dehydrated in increasing concentrations of ethanol, cleared in propylene oxide and embedded in epoxy resin. Semi-thin sections, $1 \mu \mathrm{m}$ thick were cut using an ultramicrotome, the sections were stained with toluidine blue and utilised for histological and morphometric evaluation of the Sertoli cells using Leica light microscope.

Ultrathin sections 50-90 nm thick were obtained using ultramicrotome. The ultrathin sections were stained with Reynold's lead citrate and saturated aqueous uranyl acetate. The sections were examined using a Philips CM 10 transmission electron microscope. Micrographs were produced using an Olympus Mega View III digital camera (Olympus Corporation Japan) attached to the transmission electron microscope.

\section{Cell counts and cell numbers}

The number of each cell type was determined by dividing the product of the nuclear volume density, parenchymal volume and histological correction factor (for section thickness and nuclear diameter) by the volume of a single nucleus of that cell type [17].

Volume density of each cell type was determined using a 50 point ocular reticule at $400 \times$ magnifications. The volume density was based on the number of points over nuclei of the cell type divided by total points over the testicular tissue. The mean of 20 measurements for each buck was taken as the volume density of the cell in the buck. Nuclei or nucleoli at stage 1 of the seminiferous epithelia cycle were utilised for the counting. The staging was done according to Franca et al. [13]. Nuclei or nucleoli were counted in 20 round seminiferous tubule cross sections randomly chosen from each buck. The nuclear diameter was determined using a standardised ocular micrometre inserted in the eye piece of a Leica light microscope. The correction for section thickness and nucleus and nucleolus diameter was done as described by Abercrombie [1] and modified by Amann [2].

The numbers of Sertoli cell, per gram of testis were then determined by dividing the total number of Sertoli cells by the testis weight. 
Table 1. Number and dimensions of Sertoli cells in the testes of normal and unilateral cryptorchid goats (mean \pm SEM)

\begin{tabular}{lcccccc}
\hline & \multicolumn{2}{c}{ Unilateral cryptorchid } & & \multicolumn{3}{c}{ Testes of normal goats } \\
\cline { 2 - 3 } \cline { 5 - 6 } \cline { 5 - 6 } & Retained testes & Scrotal testes & & Left & Right & Paired \\
\hline Nuclear volume density $[\%]$ & $0.95 \pm 0.51^{\mathrm{a}}$ & $1.19 \pm 0.12^{\mathrm{b}}$ & & $1.27 \pm 0.04^{\mathrm{b}}$ & $1.26 \pm 0.02^{\mathrm{b}}$ & \\
No. Sertoli cells/section of seminiferous tubule & $10.60 \pm 0.60^{\mathrm{a}}$ & $18.81 \pm 0.50^{\mathrm{b}}$ & & $12.74 \pm 0.00^{\mathrm{c}}$ & $12.13 \pm 0.32^{\mathrm{c}}$ & \\
No. Sertoli cell/testis $\left(\times 10^{9}\right)$ & $0.34 \pm 0.75^{\mathrm{a}}$ & $1.02 \pm 0.50^{\mathrm{b}}$ & & $0.61 \pm 0.27^{\mathrm{c}}$ & $0.65 \pm 0.34^{\mathrm{c}}$ & $1.25 \pm 0.82^{\mathrm{b}}$ \\
No. Sertoli cell/g testis $\left(\times 10^{6}\right)$ & $9.40 \pm 0.97^{\mathrm{a}}$ & $17.70 \pm 1.14^{\mathrm{b}}$ & & $12.53 \pm 0.86^{\mathrm{c}}$ & $12.14 \pm 0.26^{\mathrm{c}}$ & \\
Nucleolus diameter & $6.23 \pm 1.45^{\mathrm{a}}$ & $7.95 \pm 1.62^{\mathrm{b}}$ & & $7.70 \pm 1.10^{\mathrm{b}}$ & $7.85 \pm 0.56^{\mathrm{b}}$ & \\
Nuclear diameter & $13.10 \pm 0.88^{\mathrm{a}}$ & $13.67 \pm 0.54^{\mathrm{a}}$ & & $13.59 \pm 0.72^{\mathrm{a}}$ & $3.46 \pm 0.89^{\mathrm{a}}$ \\
\hline
\end{tabular}

Means with different superscript $(a, b, c)$ on the same row are significantly different $(p<0.05)$

Table 2. Germ cell/Sertoli cell ratio (mean \pm SEM) in the normal and scrotal testis of unilaterally cryptorchd goats at stage 1 of the seminiferous epithelia cycle

\begin{tabular}{lcc}
\hline & $\begin{array}{c}\text { Testis } \\
\text { (Normal } \\
\text { bucks) }\end{array}$ & $\begin{array}{c}\text { Scrotal } \\
\text { testis } \\
\text { (Cryptorchid) }\end{array}$ \\
\hline Spermatogonia & $1.70 \pm 0.06^{\mathrm{a}}$ & $1.65 \pm 0.52^{\mathrm{a}}$ \\
Primary spermatocytes & $3.27 \pm 0.13^{\mathrm{a}}$ & $5.13 \pm 0.83^{\mathrm{b}}$ \\
Round spermatids & $5.74 \pm 0.68^{\mathrm{a}}$ & $9.54 \pm 0.16^{\mathrm{b}}$ \\
\hline
\end{tabular}

Means with different superscript $(a, b)$ on the same row are significantly different $(p<0.05)$

\section{Statistical analysis}

Data were analysed using linear model procedure of SAS 6.12. Data are reported as least square means and standard error of the mean (SEM). Differences between treatment means were tested for significance using student's t-test. Significance was accepted at $\mathrm{p}<0.05$.

\section{RESULTS}

\section{Histometry}

The number of Sertoli cells and dimensions of their nuclei were presented in Table 1. The number of Sertoli cells per cross section of the testis were $10.60 \pm$ $\pm 0.60,18.81 \pm 0.50$ and $12.74 \pm 1.00,12.13 \pm 0.32$ for the abdominally retained, contralateral descended testes of the unilateral cryptorchid bucks and left and right testes of the normal bucks, respectively. The mean number of Sertoli cells per cross section of the retained testis was significantly $(p<0.05)$ lower in the retained than in the contralateral descended testes of the unilateral cryptorchid bucks and also in the left and right testes of normal bucks, respectively. Similarly the mean number of Sertoli cells per cross section of the seminiferous tubule was significantly higher in the contralateral scrotal testes of the cryptorchid bucks ( $p<0.05$ ) compared with either testis of the normal bucks. Total number of Sertoli cells in the contralateral scrotal testes of the cryptorchid bucks was significantly higher than those of the left or right testes of the normal bucks. However, there was no significant difference on comparing the total number of Sertoli cells in the contralateral scrotal testes of the cryptorchid bucks with those of the paired testes of the normal bucks.

The numbers of Sertoli cells per gram of the testis were $9.40 \times 10^{6} \pm 0.97,17.70 \times 10^{6} \pm 1.14$ and $12.53 \times 10^{6} \pm 0.86$ and $12.14 \times 10^{6} \pm 0.26$ for the retained testis, contralateral scrotal testis of the unilateral cryptorchid bucks, left and right testes of the normal (control) bucks, respectively. The numbers of Sertoli cells per gram of testes were significantly ( $p>0.05$ ) higher in the scrotal testis of the unilateral cryptorchid bucks compared with the retained testis. The numbers of Sertoli cell per gram of testis was also significantly $(p>0.05)$ higher in the scrotal testis of the cryptorchid bucks compared with the left and right testes of the normal bucks, respectively.

The mean nuclear diameters of the Sertoli cells of the retained testis, contralateral scrotal testis of the cryptorchid bucks and left and right testes of the normal bucks were $13.10 \pm 0.88 \mu \mathrm{m}, 13.67 \pm$ $\pm 0.54 \mu \mathrm{m}, 13.59 \pm 0.72 \mu \mathrm{m}$ and $13.46 \pm 0.89 \mu \mathrm{m}$, respectively. There were no significant differences in the mean diameters of the Sertoli cell nuclei and nucleoli between the contralateral scrotal testis of the naturally unilateral cryptorchid bucks and those of the normal bucks ( $p>0.05$ ).

The different germ cell/Sertoli cell ratios were illustrated in Table 2. The numbers of spermatogonia per Sertoli cell were $1.70 \pm 0.06$ and $1.65 \pm 0.52$ in the scrotal testis of the cryptorchid bucks and the 
testis of the normal bucks, respectively. The ratio of spermatogonia to Sertoli cell in the scrotal testis of the unilateral cryptorchid bucks was similar ( $p>0.05)$ to that of the testes of the normal bucks. The ratios of primary spermatocytes to Sertoli cells were $3.27 \pm$ \pm 0.13 and $5.13 \pm 0.83$ for the normal and scrotal testis of the cryptorchid bucks, respectively. The number of primary spermatocyte per Sertoli cell was significantly higher $(p<0.05)$ in the scrotal testis of the cryptorchid bucks, compared with the normal bucks.

The number of round spermatids per Sertoli cell was also found to be significantly higher $(p<0.05)$ in the scrotal testis of the cryptorchid bucks, compared with the normal bucks. However, the Sertoli cellspermatogonia ratio was similar in the contralateral scrotal testes of unilateral cryptorchids and testes of the normal bucks.

\section{Histology of Sertoli cell of the scrotal testes from unilateral cryptorchid and normal bucks}

In the light microscopy, the histology of Sertoli cells from the testes of the normal (control) bucks and those from the scrotal testis of the unilateral cryptorchid bucks were similar. The Sertoli cells were located among the developing germ cells. They were comparatively large cells that rest on the basal lamina and extended upward through the thickness of the epithelium (Fig. 1). The shape of the Sertoli cells appeared columnar. The extensions of the apical and lateral plasma membranes housed developing spermatozoa (Fig. 2). This relationship was observed in most of the stages of the seminiferous epithelium. The nucleus was found close to the base of the cell, resting on the basement membrane. The Sertoli cell nucleus was large and several different shapes were observed depending on the stage of the seminiferous cycle. The shape ranged from round, oval to irregular but all contained prominent nucleolus. Sertoli cells nuclei contained one or multiple deep indentations on their nuclear membrane, which made the nuclei, appear irregularly shaped. The nucleoplasm was typically euchromatic and stained very light blue with haematoxylin. The nucleolus was large and stood out as the only distinct intra nuclear structure (Fig. 3). The Sertoli cells processes formed occluding junctions that divided the seminiferous epithelium basal compartment (containing spermatogonia and preleptotene spermatocytes) and adluminal compartment (zygotene, pachytene and diplotene primary spermatocytes, secondary spermatocytes and spermatids).

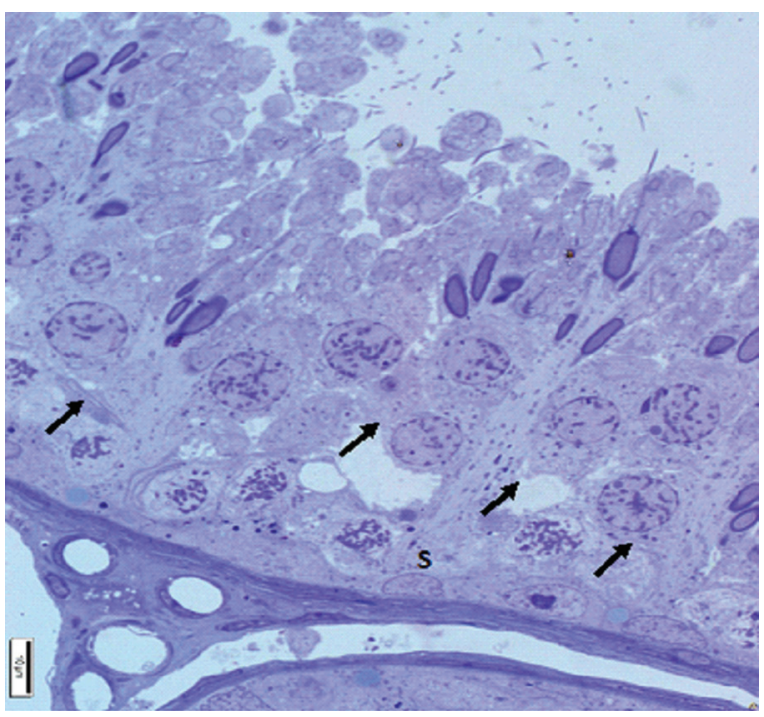

Figure 1. Stage 3 of the seminiferous epithelial cycle in the scrotal testis of the cryptorchid goat, Sertoli cell (S), with a basally located euchromatic nucleus. Note the cytoplasmic proceeses of Sertoli cells (arrows) that divided the seminiferous epithelium into basal and apical portions. Toluidine blue stain.

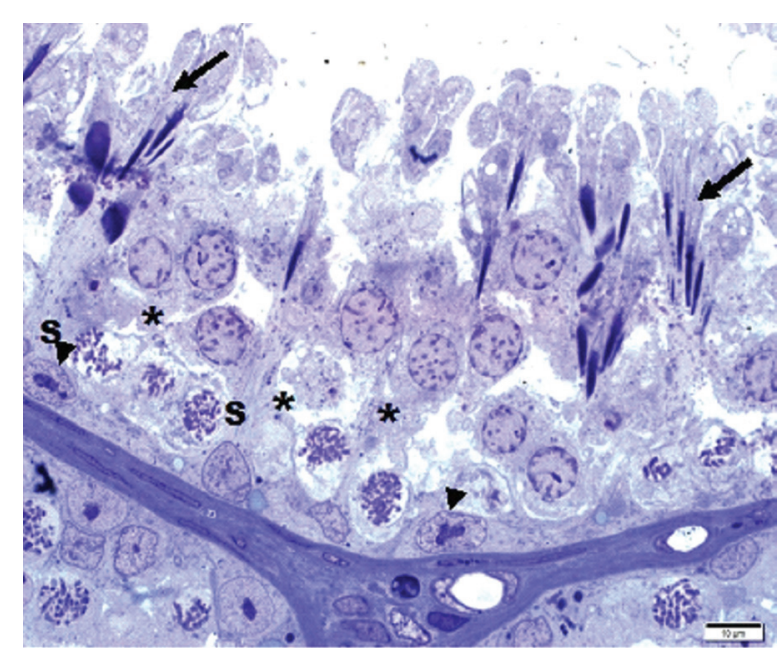

Figure 2. Stage 4 seminiferous tubule profile from normal (noncryptorchid buck) testis, showing bundles of maturing spermatids at the tips of Sertoli cell processes (arrow) and triangular shaped euchromatic Sertoli cell nucleus (S). Note the prominent nucleolus (arrow head) and cytoplasmic processes of the Sertoli cell $\left({ }^{*}\right.$ ). Toluidine blue stain.

Ultrastructural study also showed similarities between the histology of Sertoli cells in the normal testes and those of the scrotal testis of the unilateral cryptorchid bucks. The Sertoli cells were irregular in shape and contained nuclei with irregular outline (Figs. 4, 5). Numerous infoldings 


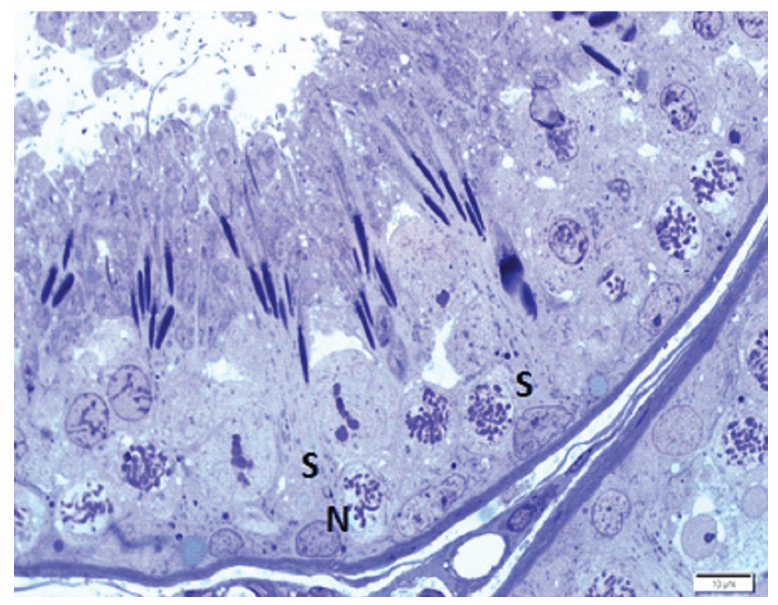

Figure 3. Stage 4 of the seminiferous tubule profile from the scrotal testis of the unilateral cryptorchid goat, showing columnar shaped Sertoli cell (S) with a basally located euchromatic nucleus (N). Toluidine blue stain.

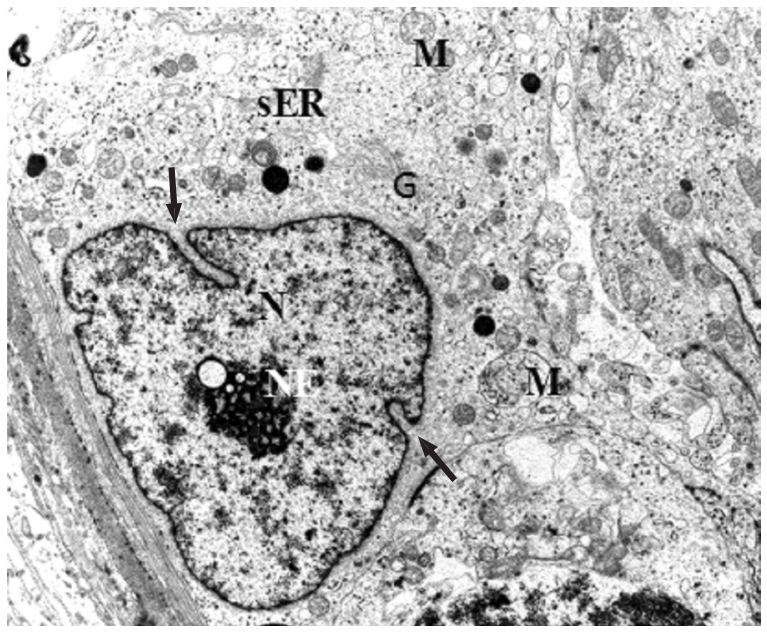

Figure 5. Electron micrograph of Sertoli cell from the testis of a normal (control) buck, showing an irregularly shaped nucleus (N), nucleolus (NE) and indentations on the nuclear envelop (arrow). The cytoplasm contains a supranuclear Golgi complex (G), mitochondria (M) and agranular endoplasmic reticulum (sER).

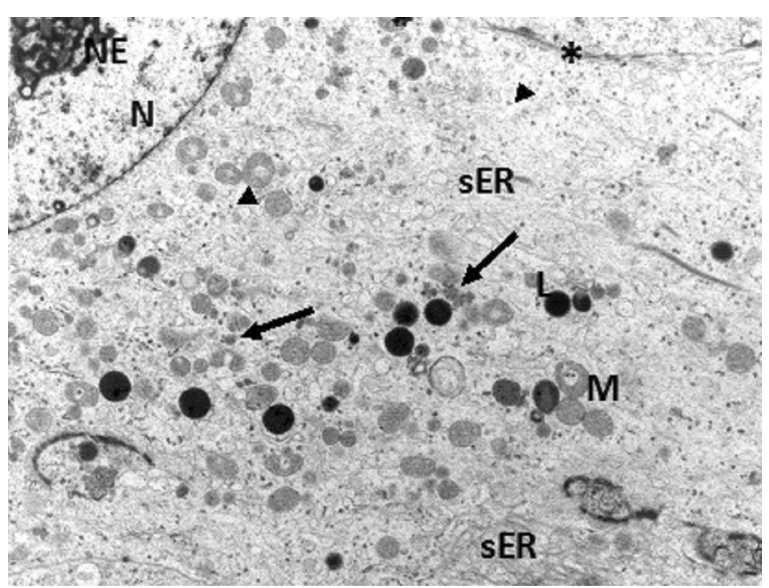

Figure 6. Electron micrograph of Sertoli cell from scrotal testis of unilateral cryptorchid, showing the basally located nucleus (N) with vesiculated nucleolus (NE) Note the polarisation of the cell with most organelles located at the apical portion. Polysomes (arrows), free ribosomes (arrow head), lysomes (L), smooth endoplasmic reticulum (sER) were randomly distributed in the cytoplasm. The junctional complex $\left({ }^{*}\right)$ is intact. were observed on the nuclear envelope. Numerous nuclear pores were also seen. The karyoplasm appeared homogeneous, however small electron dense areas were observed on the inner nuclear envelope. The nucleoli were very prominent. The cytoplasmic organelles were mostly uniformly distributed, though in some sections the distribution was polarized, the nucleus occupying the basal portion of the cell while most of the cytoplasmic organelles occupied the apical portion (Figs. 6, 7). Mitochondria were randomly distributed in the cytoplasm. Some of the mitochondria were round or oval in shape, while others were cylindrical, cup shaped or shaped like donuts. 


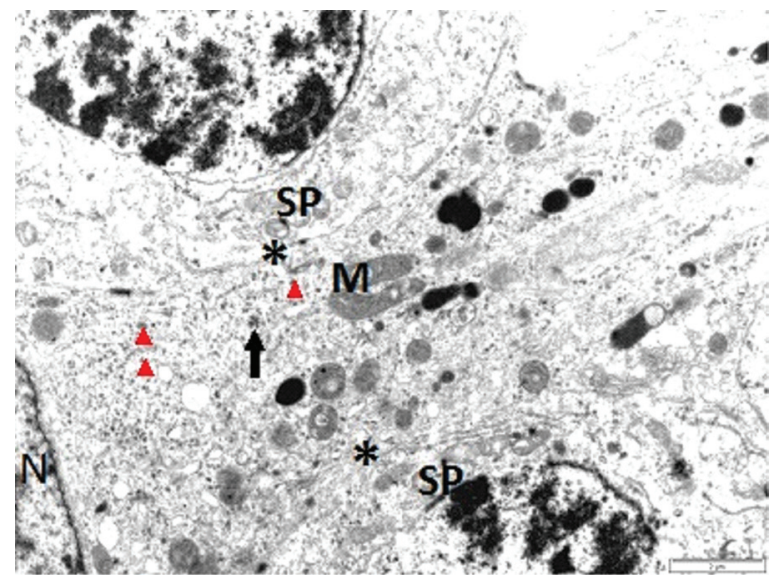

Figure 7. Electron micrograph of Sertoli cell from the testis of normal (control) bucks showing portion of the nucleus (N), cylindrical shaped mitochondria (M), polysomes (arrow) and widely distributed ribosomes (arrow heads). Note the adjacent germ cells (SP) separated from the Sertoli cell by intact germ cell-Sertoli cell junction complex $\left({ }^{*}\right)$.

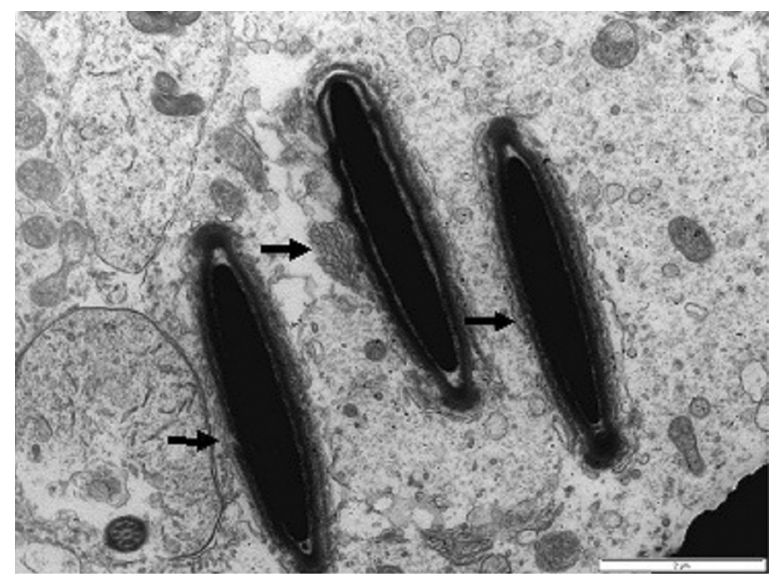

Figure 8. Electron micrograph of elongated spermatids in a scrotal testis of unilateral cryptorchid buck. Note the Sertoli cell ectoplasmic specialisation (arrows).

Rough endoplasmic reticulum profiles were randomly located in the cytoplasm. Smooth endoplasmic reticulum appeared to be the most prominent organelle found in the cytoplasm of Sertoli cells in the testes of normal bucks and contralateral scrotal testes of the unilateral cryptorchid bucks (Figs. 6, 7). Cisternae of smooth endoplasmic reticulum were often found adjacent to mitochondria or evenly dispersed within the cytoplasm or surrounding lipid droplets. Golgi bodies were small and sparingly observed in the Sertoli cells of both the control testis and the contralateral scrotal testes of the unilateral cryptorchid bucks. They were single networks of stacked saccules located at the supranuclear region of the Sertoli cell. Free ribosomes and polyribosomes were found distributed throughout the cytoplasm. Dense membrane bound bodies representing primary or secondary lysosomes were abundant in the cytoplasm. Lipid droplets of varying sizes were abundant in the basal part of the cytoplasm. The inter-Sertoli cell junctions were extensive tight junctions formed by the fusion of the peripheral leaflets of opposing Sertoli cell membranes (Figs. 6, 7). These Sertoli cell junctions divided the seminiferous epithelium into a basal compartment containing spermatogonia and preleptotene spermatocytes and adluminal compartment containing more differentiated spermatocytes and spermatids. Different types of contacts were also observed between the Sertoli cells and germ cells (Fig. 8). These include Sertoli-ectoplasmic specializations, tubulobulbar complexes and desmosome-like junctions. Sertoli-ectoplasmic specialisations were asymmetric junctional specializations that exist only at Sertoli cell side and consist of whorls of agranular endoplasmic reticulum and filaments. They were observed in the side of Sertoli cells facing elongation and maturation phase spermatids. The tubulobulbar complexes were observed as deep extensions of the spermatid plasmalemma into corresponding invaginations in the Sertoli cell (Fig. 8).

\section{Retained testis}

In the retained testis of unilateral cryptorchid bucks, Sertoli cell was the only cell type in the seminiferous tubule (Fig. 9). Each cell was in contact with the basal lamina, though the nuclei appeared at different levels as in pseudo stratified epithelium. The nucleus of the Sertoli cell was oval or irregular and showed occasional indentation on its outline. Ultrastructurally, the euchromatic nucleoplasm contained a nucleolar complex (Fig. 10). Mitochondria of different shapes were found in the cytoplasm. Clusters of cisternae of smooth endoplasmic reticulum were observed in areas close to the junctional specialisations (Fig. 11). Patches of rough endoplasmic reticulum was also present in the cytoplasm. Extensive interdigitations were observed between adjacent Sertoli cell plasma membranes (Fig. 11). The interdigitations were finger-like projections into the basal cytoplasm of adjacent cells. Desmosome like junctional complexes were located along the contact surface of the cells. The junctional complexes appeared to be intact. Some Sertoli cell profiles were characterised by cytoplasmic vacuolations, and loss of organelle outlines. Many randomly distributed mem- 


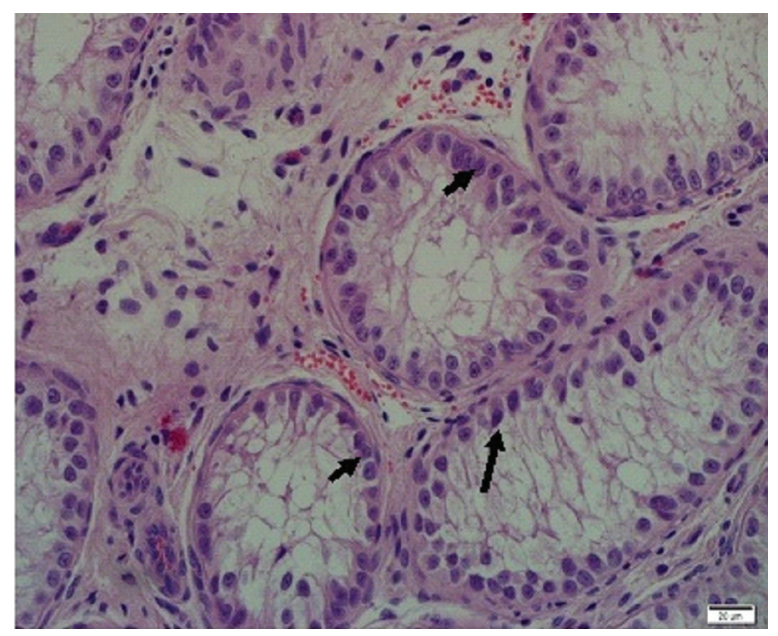

Figure 9. Seminiferous tubule profiles of retained testis of the unilateral cryptorchid buck, showing Sertoli cells (arrows) as the only cell type in the seminiferous epithelium. Haematoxylin and eosin stain.

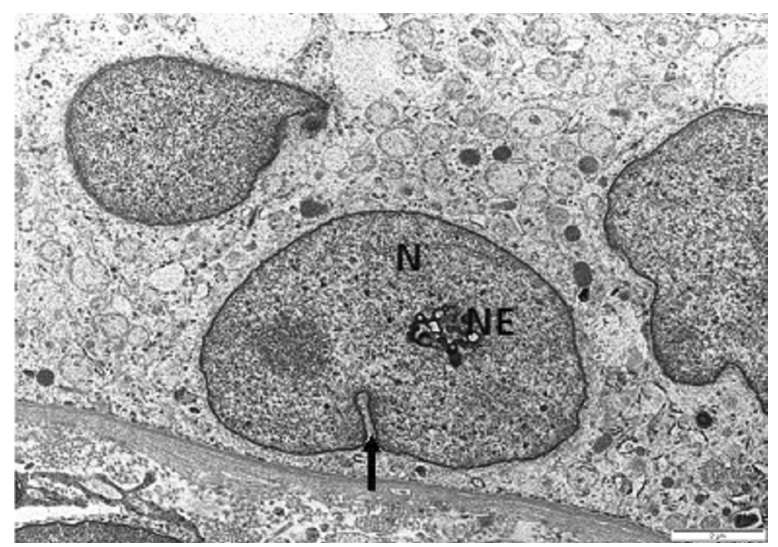

Figure 10. Electron micrograph of Sertoli cell from the retained testis of unilateral cryptorchid buch, showing a euchromatic nucleus (N), nucleolus (NE) and indented nuclear outline (arrow). Note the cytoplasmic organelles have lost their outlines.

branes bound vesicles of varying sizes and shapes were also found in the cytoplasm (Fig. 12). Free ribosomes granules were also abundant in the cytoplasm.

\section{DISCUSSION}

The mean numbers of Sertoli cells per cross section of testes, numbers of Sertoli cells per gram of testes were significantly higher in the scrotal testis of the cryptorchid bucks compared with those of the normal bucks. However, the total numbers of Sertoli cells in the single contralateral scrotal testes of the cryptorchid bucks were similar to that of the paired testes of the normal bucks. The findings in

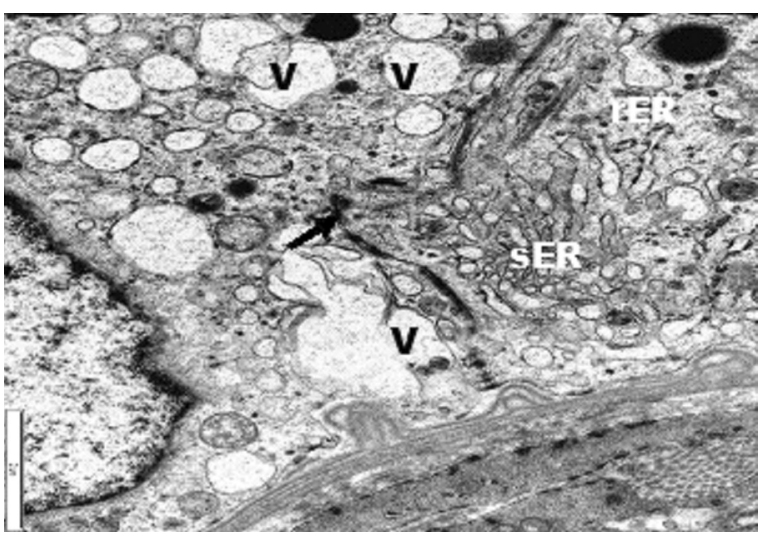

Figure 11. Electron micrograph of Sertoli cell in retained testis of unilateral cryptorchid buck. Sertoli-Sertoli cell junctions (arrow) appear intact. Clusters of smooth endoplasmic reticulum (sER) are present as well as expanded rough endoplasmic reticulum (rER). Basal cytoplasm is replete with vacuoles $(\mathrm{V}) \times 27000$.

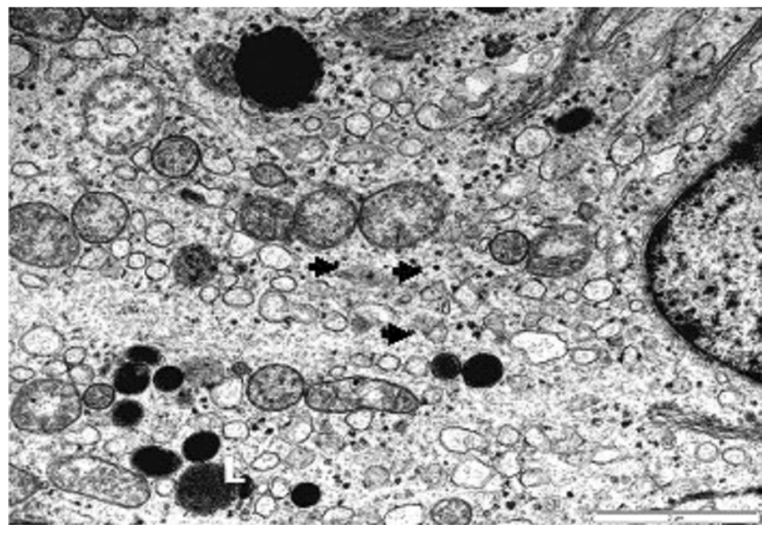

Figure 12. Electron micrograph of Sertoli cell in retained testis of unilateral cryptorchid buck. Cytoplasmic organelles have lost their outlines. Lysosomes (L) and ribosomes (arrows) are abundant in the cytoplasm.

the present study demonstrate that a single testis of the unilateral cryptorchid bucks contained as much Sertoli cells as the paired testes of the normal bucks. It is most probable that there is Sertoli cell hyperplasia in the scrotal testis of the unilateral cryptorchid bucks, to compensate for the defect observed in the contralateral retained testes. The compensatory increase in population of Sertoli cell in the contralateral scrotal testes of the unilaterally cryptorchid bucks, may be an indication that individual Sertoli cell would need to provide bloodtestis barrier over a reduced physical area. This phenomenon possibly maximizes their potentials for 
improved spermatogenesis. Therefore, the similarity in the number of Sertoli cells in the scrotal testis of unilateral cryptorchid bucks and the normal bucks may be an indication that unilateral cryptorchid bucks produce similar sperm output as the normal bucks.

In the present study, the germ cell-Sertoli cell ratio was significantly higher in the contralateral testes of the unilateral cryptorchid bucks compared with the normal bucks. It is then most probable that the Sertoli cells in the contralateral scrotal testes of the cryptorchid bucks are more efficient in supporting spermatogenesis. It has been reported that spermatid - Sertoli cell ratio is the determinant of the workload and function of the Sertoli cell [19] and spermatogenic efficiency [12]. The spermatid-Sertoli cell ratio is an important marker of spermatogenesis as it has been demonstrated that relative changes in daily sperm production would adjust the number of spermatids supported by the Sertoli cell population [27]. Thus the only functional testis of the unilateral cryptorchid underwent hyperplasia and enhanced functional capability to compensate for loss of function of the opposite contralateral retained testes.

Morphological features of the Sertoli cells were similar in the contralateral scrotal testes of the unilaterally cryptorchid bucks and the testis of the normal bucks and they conform to the general description of Sertoli cells in other mammals [18]. The morphological similarities observed, demonstrate that abdominal retention of one testis in unilateral cryptorchidism does not affect the morphology of the contralateral descended scrotal testis. This finding is at variance with an earlier report of bilateral testicular impairment in the unilateral cryptorchid males due to auto sensitisation [26]. The disparity in the findings may be due to variations in species and experimental methods.

The results of the present study also showed that retention of testes in the abdominal cavity produced changes in the morphology of the Sertoli cells in the retained testis. The sequence of changes may be a response of the Sertoli cells to increased temperature and absence of spermatogenic cells interacting with Sertoli cells. Cytoplasmic vacuolations of Sertoli cells has been reported in the testes of many mammals in various conditions including vitamin A deficiency in the rat [7] simulated high altitude in hamster and in patients with infertility of various aetiologies [5].

\section{CONCLUSIONS}

In the retained testes, Sertoli cell junctional complex showed normal histological appearance. This normal morphology is most probably an indication that the integrity of the junctional complexes were not compromised as a result of the supra-scrotal temperature in the abdomen. Similar opinions were expressed by Hagenas et al. [15] in experimental cryptorchid rats and by Singh and Ezeasor [28] in naturally hemicryptorchid goats. However, the result of the present study is at variance with those of Aumuller et al. [3] and Turner et al. [30], who reported some modifications in the architecture of junctional complexes, implying break down of blood/testis barrier. There are no obvious explanations for this discrepancy.

\section{REFERENCES}

1. Abercrombie M (1946) Estimation of the nuclear population from microtome sections. Anat Rec, 94: 238-248.

2. Amann RP (1962) Reproductive capacity of diary bull. III. The effect of ejaculatory frequency, unilateral vasectomy and age on spermatogenesis. Am J Anat, 110: 49-67.

3. Aumuller G, Hartman K. Giers U Schenk B (1980) Fine structure of Sertoli cells of the testis in experimental cryptorchidism. Int J Androl, 3: 301-311.

4. Azari O, Gholipour H, Kheirandish R, Babaei H, Emadi L (2013) Study of the protective effect of vitamin C on testicular tissue following experimental unilateral cryptorchidim in rats. Andrologia, 46: 495-503.

5. Chen IL, Yates RD (1974) Effects of simulated high altitude on hamster testes. Anat Rec, 178: 326-330.

6. Chiejina SN, Behnke JM (2011) The unique resistance and resilience of the Nigerian West African Dwarf goat to gastrointestinal nematode infections. Parasite Vectors, 4: $12-14$

7. Doyle TJ, Oudes AJ, Kim KH (2009) Temporal profiling of rat transcriptomes in retinol replenished Vitamin A deficient testis. Syst Biol Reprod Med, 55: 145-163.

8. Emehelu CO, Ekwueme EC, Chah FK (2005) Cryptorchidism in West African Dwarf goat in Nsukka Agricultural zone of Enugu State, Nigeria. Sahel J Vet Sci, 4: 59-61.

9. Ezeasor DN (1985) Light and electron microscopical observations on the Leydig cells of the scrotal and abdominal testes of naturally unilateral cryptorchid West African Dwarf goats. J Anat, 141: 27-40.

10. Ezeasor DN (1989) Ultrastructure of Sertoli cells in cryptorchid goats. Arch Androl, 23: 61-70.

11. Ezeasor DN, Singh A (1987) Morphologic features of Sertoli cells in the intrabdominal testes of cryptorchid dwarf goats. Am J Vet Res, 48: 1736-1745.

12. Franca LR (1992) Daily sperm production in Piau boars estimated from Sertoli cell population and Sertoli cell index. In: Proceedings of the 12th International Congress on Animal Reproduction and Artificial Insemination, Hague, Netherlands: ICAR. 4, pp 1716-1718. 
13. Franca LR, Becker-Silva SC, Chiarini H (1999) The length of seminiferous epithelium in goats (caprahircus). Tissue Cell, 31: 274-280.

14. Giwercman A, Bruun E, Frimont-Moller C, Skakkebaek NE (1993) Abnormalities in testes of men with history of cryptorchidism. J Urol, 150: 671-674.

15. Hagenas L, Ploen L, Ritzen EM (1976) Blood-testis barrier: maintained function of inter-sertoli cell junction in experimental cryptorchidism in the rat, as judged by a simple lanthanum-immersion technique. Andrologia, 9: 3-7.

16. Johnson L, Carter GK, Varner DD, Taylor TS, Blanchard TL, Rembert MS (1994) The relationship of daily sperm production with number of Sertoli cells and testicular size in adult horses: role of primitive spermatogonia. J Reprod Fertil, 100: 315-321.

17. Johnson L, Neaves WB (1981) Age-related changes in the Leydig cell population, seminiferous tubules and sperm production in stallions. Biol Reprod, 24: 703-712.

18. Johnson L, Thompson DL Jr, Varner DD (2008) Role of Sertoli cell number and function on regulation of spermatogenesis. Anim Reprod Sci, 105: 23-51.

19. Johnson L, Zane RS, Petty CS, Neaves WB (1984) Quantification of the human Sertoli cell population: its distribution, relation to germ cell numbers, and agerelated decline. Biol Reprod, 31: 785-795.

20. Kamisawa $\mathrm{H}$ (2012) Attenuation of spermatogonial stem cell activity in cryptorchid testes. J Urol, 187: 1047-1052.

21. Mitchell T (2003) How to tell the age of goats. (reviewed edition) Division of animal production, New South Wales Department of Agriculture Dubbo.

22. Moritoki Y, Hayashi Y, Mizuno K, Kamisawa H, Kurokawa S, Ugawa S, Kojima Y, Kohri K (2014) Expressing profiling of microRNA in cryptorchid Testes: miR-135a contributes to the maintenance of Spermatogonial Stem Cells by Regulating FoxO1. J Urol, 191: 1174-1180.

23. Oyeyemi MO, Matthew OA, Olufunke EO (2000) Effect of successive ejaculations on the spermiogram of West African Dwarf goats (Capra hircus.). Veterinarski Arhiv, 70: 215-221.

24. Oyeyemi MO, Samuel GO, Ajayi, TA, Adeniji DA (2011) Semen characteristics and sperm morphological studies of the West African Dwarf Buck treated with Aloe vera gel extract. Iranian J Reprod Med, 9: 83-88.

25. Pinart E, Camps R, Briz MD, Bonet $S$ (1996) Sperm quality in spontaneous unilateral abdominal cryptorchid boars. Int J Dev Biol, suppl. 1: 228-268.

26. Rost A, Ehrenberg W, Fiedler U (1981) Determination of auto antibodies against spermatozoa in experimental cryptorchidism. Urol Int, 36: 59-66.

27. Russell LD, Peterson RN (1984) Determination of the elongate spermatid-Sertoli cell ratio in various mammals. J Reprod Fertil, 70: 635-664.

28. Singh A, Ezeasor DN (1989) Ultrastructure of Sertoli cells in scrotal testis of unilateral cryptorchid goat. Dev Ultrastr Reprod, 296: 159-164.

29. Thompson TL, Berndtson WE (1993) Testicular weight, Sertoli cell number, daily sperm production, and sperm output of sexually mature rabbits after neonatal or prepubertal hemicastration. Biol Reprod, 48: 952-957.

30. Turner TT, D'Addario DA, Forrest JB, Howards SS (1982) The effect of experimental cryptorchidism on the entry of $[3 \mathrm{H}]$ - inulin and $[3 \mathrm{H}]$ - horse radish perioxidase in the lumen of the rat seminiferous tubules. J Androl, 3: 178.

31. Veronesi MC, Riccardi E, Rota A, Grieco V (2009) Characteristics of cryptic/ectopic and contralateral scrotal testes in dogs between 1 and 2 years of age. Theriogenology, 72: 969-977. 